\title{
Employment Protection Laws and Privatization
}

\author{
Krishnamurthy Subramanian Indian School of Business \\ William Megginson University of Oklahoma
}

\begin{abstract}
Is privatization in a country related to the stringency of its employment protection laws (EPLs) - and, if so, how? We address these questions using privatization deals in 14 European countries over 3 decades and the changes in EPLs in a country. Using traditional difference-in-differences tests exploiting major changes and generalized difference-in-differences tests for the full sample, we find that stringent EPLs discourage privatization. For identification, we use two sets of triple-difference tests that control for country-level omitted variables using fixed effects for each country-year pair. First, using cross-sectional differences across industries in a country, we find that the effect of EPLs on privatization is disproportionately greater in industries in which separation rates and relocation rates are higher. Second, using productivity measures for US industries as an instrument, we find that the effect of EPLs on privatization is disproportionately greater in less productive industries.
\end{abstract}

\section{Introduction}

A central question in the law, economics, and finance literatures asks how employment protection laws (EPLs) affect the macroeconomic performance of national economies and the output, leverage, profitability, and costs of capital for individual companies. Early studies such as Lazear (1990), Blanchard and Portugal (2001), Saint-Paul (2002), Besley and Burgess (2004), and Botero et al. (2004) show that labor regulations could have first-order economic impacts. More recent research such as Atanassov and Kim (2009), Agrawal and Matsa (2013), Acharya,

We would like to thank Chandra Sekhar Mangipudi for excellent research assistance and Sam Peltzman, the referee, Viral Acharya, Gayle Allard, Andrea Bassanini, Tor-Erik Bakke, Ginka Borisova, John Earle, Louis Ederington, Perin Erin, Mara Faccio, Chitru Fernando, Edith Ginglinger, Janya Golubeva, Nandini Gupta, Claude Laurin, Ed Lazear, John Leahy, Scott Linn, John McConnell, N. Prabhala, Manju Puri, Martin Rama, Gilles Saint-Paul, Raghuram Rajan, Andrei Shleifer, Raghu Sundaram, Vahap Uysal, Pradeep Yadav, Ania Zalewska, Luigi Zingales, and seminar participants at the Indian School of Business Finance Research Workshop, the 2011 Multinational Finance Society meeting (Rome), Deakin University, Massey University, Nanyang Technological University, Purdue University, and the University of Oklahoma for helpful comments. All errors are our own.

[Journal of Law and Economics, vol. 61 (February 2018)]

(C) 2018 by The University of Chicago. All rights reserved. 0022-2186/2018/6101-0004\$10.00 
Baghai, and Subramanian (2013, 2014), Simintzi, Vig, and Volpin (2015), and Alimov (2015) document that such labor regulations-and especially changes in EPLs or in the power of unions-significantly affect firm-level costs and market values. We contribute to this research by studying the following questions: Is privatization, through public share offering or private sale, in a country affected by the stringency of its EPLs? In particular, do stringent EPLs encourage or discourage privatization? We show that strengthening (weakening) employment protection discourages (encourages) privatization in subsequent periods and document that these effects are economically large.

Studying these questions is important for several reasons. First, privatization, broadly defined as the deliberate sale by a government of state-owned enterprises (SOEs) to private investors, has been a centerpiece of national economic policy over the last 3 decades. Megginson (2017) documents that privatization programs raised over $\$ 3.63$ trillion globally since 1988 , mostly through public share offerings, and over $\$ 1.26$ trillion was raised since $2012 .{ }^{1}$ Privatization has been instrumental in transforming the size and efficiency of almost all capital markets outside the United States (Boutchkova and Megginson 2000; Bortolotti and Faccio 2009). In fact, governments view share issue privatizations as one of their most powerful tools for promoting capital market development (Megginson et al. 2004). Similarly, EPLs form an important instrument of a nation's policy tool kit by affecting economic efficiency and employees' welfare (Lazear 1990; Allard 2005; Acharya, Baghai, and Subramanian 2013, 2014; Simintzi, Vig, and Volpin 2015; Alimov 2015). In fact, few other combinations of country-level variables affect so many economic agents simultaneously-workers, firms, government, investors, and even consumers - and in such powerful ways as do EPLs and privatization.

Second, while the law, economics, and finance literatures have examined the effects of labor laws on employment, productivity, and output (see Section 2), the effect of labor laws on privatization has received less attention. Yet simple theoretical arguments highlight why EPLs are likely to be a key determinant of privatization. Politicians exercise control over SOEs, and organized labor, particularly labor unions, represents a key interest group to which politicians cater (Shleifer and Vishny 1994; Boycko, Shleifer, and Vishny 1996; Dinç and Gupta 2011; Chen et al. 2015). As Shleifer and Vishny (1994) argue, maximizing employment in SOEs remains the implicit objective of politicians, since disbursing patronage to organized labor constitutes an important tool for politicians to create and/or enhance their political capital. Not surprisingly then, SOEs employ excess workers

\footnotetext{
${ }^{1}$ Despite the large scale of privatization programs to date, governments still retain immensely valuable assets, and state-owned enterprises (SOEs) remain important-sometimes dominantplayers in many industries. The Economist (2014) estimates that governments around the world own nonfinancial assets worth over $\$ 9$ trillion. The Organisation for Economic Co-operation and Development (OECD 2014) documents that SOEs account for roughly 2 percent of employment in rich countries. Outside the OECD, state enterprises account for significantly higher shares of aggregate industrial output and employment. Given these large stakes, governments could also raise large sums by selling stock currently held in fully or partially state-owned companies.
} 
and employ them inefficiently when compared with privately owned firms. ${ }^{2}$ Since new private investors may need to lay off employees to maximize shareholders' value, politicians fear that privatization will result in large-scale labor force restructuring and thus adversely affect the key voting support that organized labor provides. Since labor retrenchment is regulated in most developed countries through EPLs, these may affect privatization significantly.

Finally, theory provides ambiguous predictions for the effect of EPLs on privatization. On one hand, by imposing restrictions on the retrenchment of employees, stringent EPLs constrain a new owner's ability to increase a firm's efficiency through staffing changes postsale. Stronger EPLs impose hurdles on laying off old or hiring new employees, even if new private owners might need to retrench existing employees and hire new ones in greater numbers to achieve the efficient level and quality of employment, respectively. If these hurdles are binding and material, strengthening EPLs should not only reduce the probability that certain companies will be privatized but should also decrease the price that private investors will be willing to pay for divested companies.

On the other hand, stringent EPLs can foster risk-taking by employees and thereby enhance firm-level efficiency (Acharya, Baghai and Subramanian, 2013, 2014). Because SOEs are quite inefficient (Shleifer and Vishny 1994; Banerji and Sabot 1994; Dewenter and Malatesta 2001; Dinç and Gupta 2011; Megginson 2017), private investors may prefer to invest in privatization programs in stringent EPL environments to enhance firm-level efficiency. In addition, stringent EPLs could encourage privatization by reducing union opposition to privatization because such EPLs may reduce employees' fears of retrenchment postprivatization. Given politicians' concerns about the voting support of organized labor, politicians may have fewer concerns about privatization in stringent EPL environments. These opposing theoretical predictions motivate an interesting empirical study.

To test these hypotheses, we obtain data on privatizations from the Privatization Barometer (PB) database, which contains a comprehensive list of divestment transactions from 1978 onward for Western European Union (EU) countries. We use the EPL index presented in Allard (2005), which analyzes in detail the evolution of EPLs across Organisation for Economic Co-operation and Development (OECD) countries from 1950 to 2003 to generate the index. The Allard index comprehensively covers all aspects of EPL and includes the universe of changes in laws pertaining to employment protection in OECD countries. In addition, the index exhibits considerable within-country variation that is generated by specific changes in law.

Our sample comprises 14 European countries for which both EPL and PB data are available. We find that both sets of data exhibit substantial variation in the countries in our sample. Overall, the EPL index captures 57 changes in 14 coun-

\footnotetext{
${ }^{2}$ It is now well established that SOEs employ excess workers relative to more efficient levels that would be expected under private ownership (see Banerji and Sabot 1994; LaPorta and López-deSilanes 1999; Dewenter and Malatesta 2001; Dinç and Gupta 2011). Du and Liu (2015) also show that governments are very reluctant to privatize SOEs that are performing poorly (due largely to overstaffing) even when unconstrained from doing so.
} 
tries over 26 years (1978-2003)-35 increases and 22 decreases in stringency. This variation in EPLs is richer than the OECD index used in Simintzi, Vig, and Volpin (2015), which captures 21 changes in EPLS in 21 countries over 23 years (1985-2007). Many changes in EPLs occurred in the late 1970s and early 1980s, which the index in Simintzi, Vig, and Volpin (2015) does not capture because it begins in 1985 .

Our key finding is that stringent EPLs discourage privatization. We establish this finding using two sets of tests. First, we conduct traditional difference-indifferences tests that exploit within-country variation generated by major changes in EPLs. We employ several specifications that control for various country-level omitted variables and potential sources of endogeneity in EPLs. Second, as the centerpiece of our identification strategy, we undertake triple-difference tests by interacting country-level EPLs with industry-level measures for the likelihood of employees' turnover and productivity. The key distinguishing feature of these triple-difference tests is that we control for all country-level variables by including fixed effects for each country-year pair in our sample. Thus, we control for the effect of every observed and/or unobserved variable that varies at the countryyear level and then exploit differences among industries within a country-year to estimate the effect of EPLs on privatization. In these triple-difference tests, we find that the effect of EPLs on privatization is disproportionately greater in industries where the separation rate is greater, total worker reallocation rates are greater, workers' productivity is lower, and union density is higher. Since the United States is not part of our sample, and since labor market frictions are significantly lower at the federal level in the United States than in Europe, we use the measure of productivity for US industries as an instrument for the benchmark efficient level of productivity in an industry in a country in our second set of tripledifference tests. Since the efficiency gains from shedding excess labor would be greatest in less productive industries, these findings provide further confirmation of the hurdles imposed by EPLs as the key mechanism in play.

The economic effect of EPLs on privatization is significant. Using the difference-in-differences estimates, we conclude that a 1-standard-deviation increase in the stringency of EPLs is associated with a \$.94 billion increase in the value of privatization deals per year, approximately two additional privatization deals per year, and a $\$ 96.8$ million per deal increase in the average value of privatization deals per year. When compared with the standard deviations of these variables, these translate into increases of about 29,49 , and 21 percent, respectively. The magnitudes using the triple-difference tests are similar.

To ascertain robustness, we rerun our tests using the OECD's employment protection level index on which the Simintzi, Vig, and Volpin (2015) index is based, which enables us to extend our sample to 2013. Our results remain unchanged, which is consistent with the robust results that Simintzi, Vig, and Volpin (2015) find using alternative EPL indices. In sum, across a plethora of tests, we find that stringent EPLs deter privatization in our sample of 14 countries. In fact, we find that compared with other country-level policy variables, such as equity and/or credit market development, flexible EPLs affect privatization significantly more 
in these countries. From a policy-making standpoint, since labor restructuring is the most sensitive issue surrounding privatization, our study highlights that if national governments would ease the rigidities in their labor markets before embarking on a privatization exercise, they would be able to raise significantly more in proceeds from privatization.

This study is organized as follows. We review the related literature in Section 2, while Section 3 discusses possible political-economic influences on changes in EPLs and privatization. Section 4 presents the data and proxies we examine. Section 5 presents empirical results and robustness checks, while Section 6 examines alternate identification strategies using triple-difference tests controlling for country-level variables. Section 7 concludes.

\section{Related Literature}

Our study relates broadly to three streams of the financial economics literature: the literature on law and finance, especially that relating to EPLs; the literature on privatization; and the literature examining the interaction between labor policies and corporate financial decisions. With respect to the law and finance literature (La Porta et al. 1997, 1998; La Porta, Lopez-de-Silanes, and Shleifer 1999), our paper is the first to examine the effect of country-level laws on privatization. Our study specifically relates to La Porta, Lopez-de-Silanes, and Shleifer (1999), which examines the effect of shareholders' legal protection on corporate ownership around the world. In contrast, we examine the effect of laws affecting the relationship between employers and employees on the ownership structure of firms, specifically the transition from state to private ownership. With respect to the law and finance literature, our work also relates to studies examining the real effects of EPLs (see Lazear 1990; Ljungqvist and Sargent 1998; Botero et al. 2004; Besley and Burgess 2004; Acharya, Baghai, and Subramanian. 2013, 2014; Alimov 2015; Simintzi, Vig, and Volpin 2015; Dessaint, Golubov, and Volpin 2017). We contribute to this literature by showing that stringent EPLs discourage privatization.

Second, our study relates to the literature examining the relationship between privatization and labor. López-de-Silanes (1997) finds that labor force restructuring before privatization increases the price of privatization. In contrast, we find no effect of EPLs on the price. Instead, stringent EPLs reduce the number and dollar volume of privatization transactions. These differences vis-à-vis López-de-Silanes (1997) are not unexpected for the following reasons. If labor force restructuring before privatization brings employment to efficient levels, as in López-deSilanes's study, EPLs should have no effect on privatization. In contrast, the negative effect of stringent EPLs on the number and dollar volume of privatization that we find suggests that labor force restructuring before privatization may not suffice to bring the quantity and quality of the labor force in SOEs to efficient levels. Consistent with this phenomenon, several studies provide evidence of labor force restructuring after privatization (see Chong, Guillen, and López-de-Silanes 2011; D’Souza and Megginson 1999; LaPorta and López-de-Silanes 1999).

Finally, our study relates to the emerging literature on the interaction between 
labor policies and corporate finance (see DeAngelo and DeAngelo 1991; Pagano and Volpin 2005; Fauver and Fuerst 2006; Faleye, Mehrotra, and Morck 2006; Atanassov and Kim 2009; Klasa, Maxwell, and Ortiz-Molina 2009; Matsa 2010; Bae, Kang, and Wang 2011; Chen, Kacperczyk, and Ortiz-Molina 2011; Agrawal 2011). We contribute to this literature by examining how EPLs affect the transition from state to private ownership.

\section{The Political Economy of Employment Protection Laws and Privatization}

\subsection{The Political Economy of Employment Protection Laws}

Employment protection laws are often driven by political considerations: countries with a longer history of left-leaning governments tend to have more stringent labor regulation (Botero et al. 2004). Consistent with such an association, Deakin, Lele, and Siems (2007) also document that the primary motivation for labor market (de-)regulation is political. For example, they find that a considerable decrease in the intensity of labor market regulation in the United Kingdom during the 1980s and early 1990s coincided with the election of a Conservative government committed to labor market deregulation. Similarly, they report that a limited renaissance of the regulation of labor markets in the United Kingdom was triggered by the return to office in 1997 of a Labour Party government, which also ended the United Kingdom's opting out of the European Social Charter. In France, the election of a Socialist Party government in 1981 led to a series of labor law reforms aimed at shifting the balance of power toward employees: the Auroux laws. These laws, which were enacted in 1982 under the presidency of François Mitterrand, covered a wide range of aspects in both individual and collective labor law. Since that time, French labor law has mirrored changes in the distribution of power between the main political parties (Deakin, Lele, and Siems 2007).

While political forces are critical in shaping labor regulation, Saint-Paul (2002) argues that the political impetus for EPLs is itself closely linked to economic growth in a country. He asserts that higher rates of economic growth reduce the political support for dismissal laws. However, since incumbent workers are most fearful of losing jobs during periods of slow economic growth, the level of political support for dismissal laws should be high in such periods. As empirical evidence for his thesis, Saint-Paul (2002) points out that employment protection increased in many European countries in the early 1970s and was difficult to reduce in the 1980s, a period of slow economic growth.

\subsection{Simultaneous Effects on Employment Protection Laws and Privatization}

Left-leaning governments are not only more likely to enact stringent EPLs, they are also less likely to privatize public enterprises. Therefore, a simultaneous determination of EPLs and privatization can result from a change in national government that brings an ideologically charged party to power. This arguably is the case for the Thatcher government in the United Kingdom; elected in 1979, 
it implemented dramatic reductions in the stringency of Britain's EPLs-which were already fairly weak compared with contemporaneous laws in most other EU countries - and adopted an increasingly sweeping privatization program in 1981-90. Both major policy changes were motivated by the same powerful liberalizing impulse, so it might be argued that changes in EPLs did not cause changes in privatization scale and frequency but instead that they were codetermined.

The Thatcher phenomenon highlights a possible concern that we recognize in our empirical analysis: the career concerns of politicians and/or their ideological leanings leading to a simultaneous determination of EPLs and privatization. Also, a change in the political economy may affect not only the passage of EPLs but also the government's reservation price for privatization and the private sector's willingness to pay for SOEs. Empirical analyses of possible interactions among changes in EPLs, privatization, and political forces are presented in Section 5.3.

\section{Data and Proxies}

\subsection{Proxies for Privatization}

Our privatization data are from the $\mathrm{PB}$ database, which is the principal online database of privatization transactions in the European Union. The PB database is fully searchable and contains a comprehensive list of privatization transactions from 1978 onward for all EU countries. Privatization Barometer is the official provider of privatization data to the OECD and the World Bank. Our sample begins in 1978 and ends in 2003 since the data on EPLs are available only through 2003. After combining the PB data with those of EPLs, we have 364 observations (14 countries $\times 26$ years) for a balanced panel of 14 countries in 1978-2003.

We conduct our empirical tests at the country-year and country-industry-year levels to avoid econometric issues that manifest in tests at the firm level. Apart from the fact that neither EPLs nor the relative effect of EPLs in different industries varies at the firm level, unobserved firm-specific factors coinciding with the timing of privatization would be a first-order determinant of whether a particular firm is privatized. Such unobserved firm-specific factors coinciding with the timing of privatization would cloud inference of the effect of EPLs on privatization.

As our primary proxy for privatization, we employ the total value of privatization deals (in current US\$billions) at two levels of aggregation: the country-year level and the country-industry-year level. We employ these levels rather than the number of privatization deals because of the extreme asymmetry in the size of privatization sales (Megginson et al. 2004). We also perform tests using number of privatization deals instead of total value and the average price paid per privatization deal.

Table 1 shows summary statistics for privatization in the 14 countries that form our sample. From 1978 to 2003, the United Kingdom privatized more than any other country with respect to both the number of privatizations and the dollar value of these transactions. 


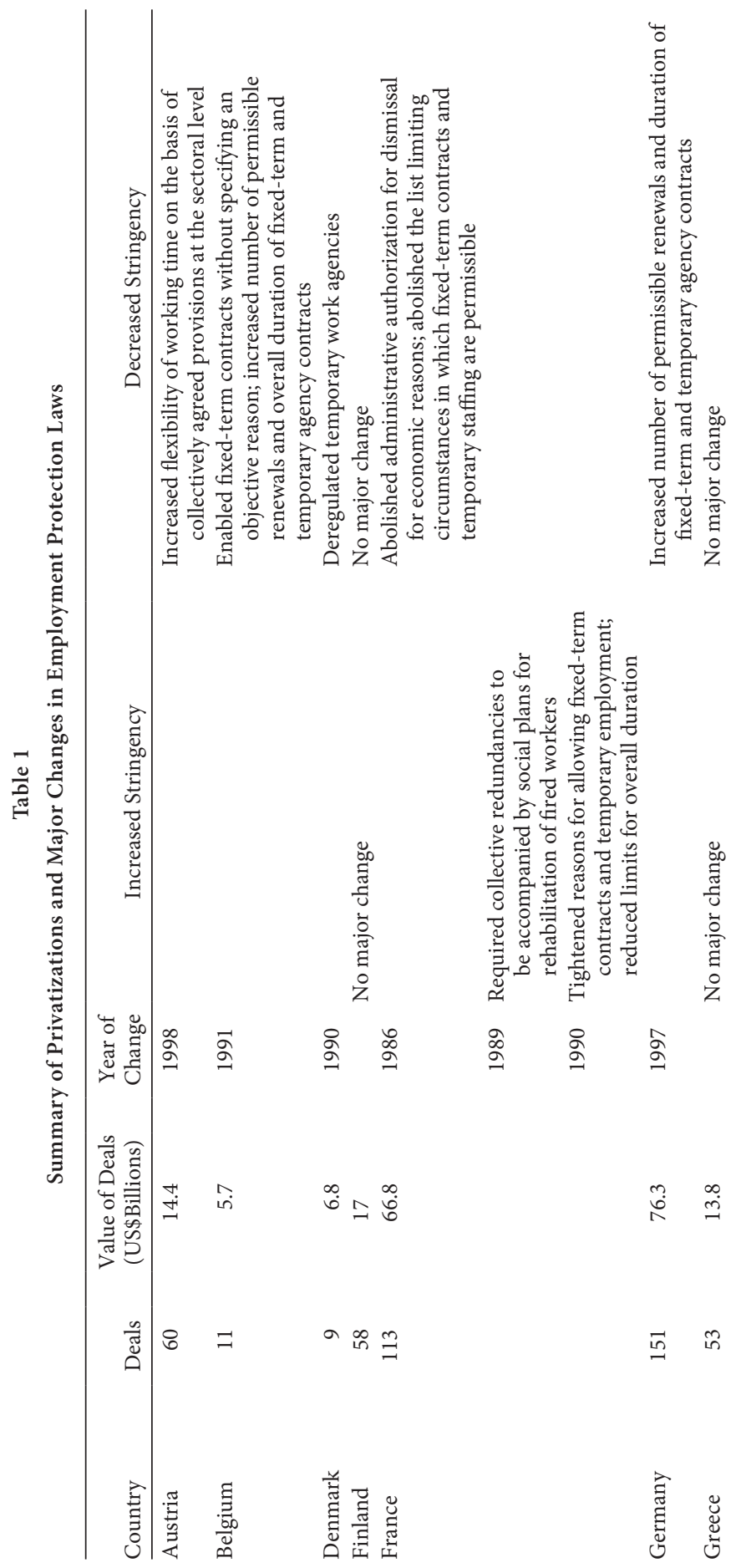

This content downloaded from 202.174.120.162 on June 08, 2019 06:35:35 AM All use subject to University of Chicago Press Terms and Conditions (http://www.journals.uchicago.edu/t-and-c). 

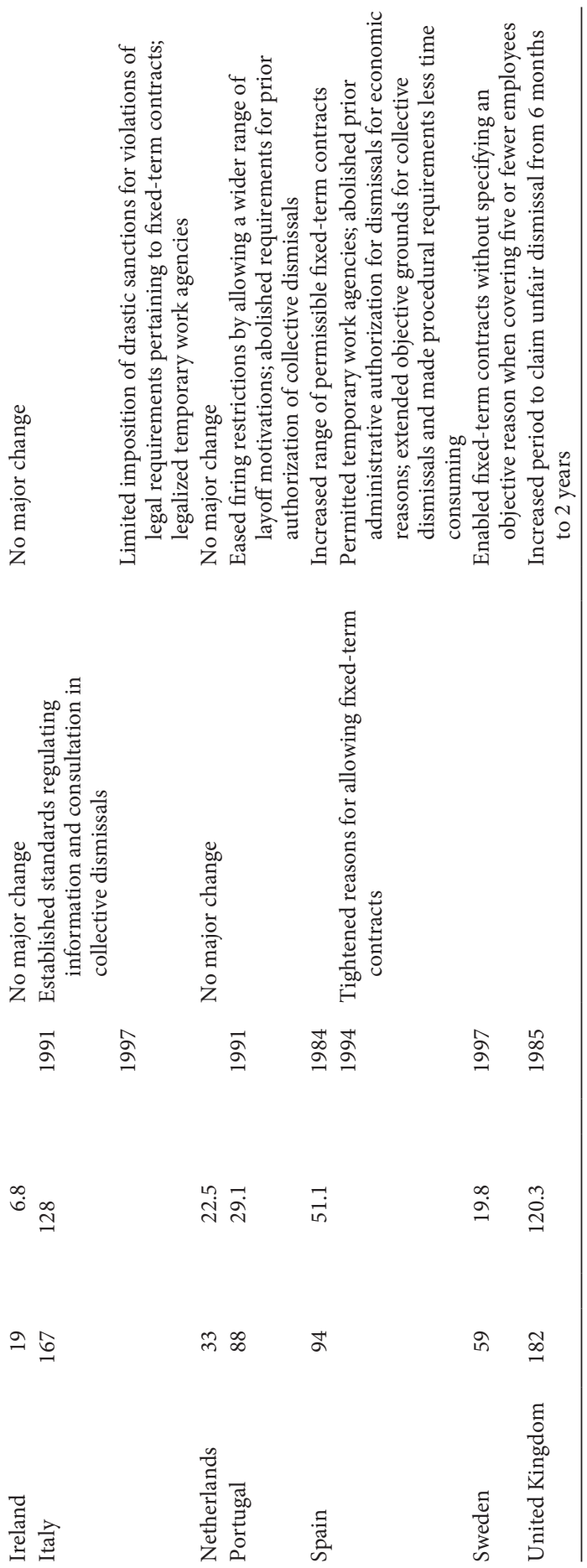

This content downloaded from 202.174.120.162 on June 08, 2019 06:35:35 AM All use subject to University of Chicago Press Terms and Conditions (http://www.journals.uchicago.edu/t-and-c). 


\subsection{Employment Protection Laws}

To analyze the impact of EPLs on privatization, we exploit the time-series variation generated by changes in these laws in EU countries. We use the EPL index from Allard (2005), which includes EPLs across OECD countries from 1950 to 2003.

\subsubsection{Comparison of Indices}

When compared with alternative indices for employment protection such as those in Botero et al. (2004) or in Deakin, Lele, and Siems (2007), Allard's index offers two key advantages in the context of our study. ${ }^{3}$ First, the long time series, which captures all country-level changes in EPLs, enables us to examine withincountry correlation between changes in EPLs and privatization, which reduces the econometric concerns that arise in a cross-country setting. Second, it provides complete coverage of all aspects of EPLs in OECD countries. Moreover, the Allard index has been employed in several recent studies that examine various effects of employment protection, including Alimov (2015) and Simintzi, Vig, and Volpin (2015). Nevertheless, to assure ourselves that the results are not specific to this index, we also examine the robustness of our results using the OECD index (OECD 2014). Because the OECD index is available only from 1985 onward and several changes in EPLs in our sample of countries occurred before then, we employ the OECD index to examine the robustness of our results rather than as the main index of interest. Figure OA1 in the Online Appendix shows that, for our sample of countries from 1985 to 2003, the Allard (2005) and the OECD indices correlate strongly, at .74. Simintzi, Vig, and Volpin (2015) document similar correlations.

\subsubsection{Description of the Allard Index}

The EPL index we use was constructed by surveying existing law and regulations in OECD countries and assigning numerical scores for every aspect of EPLs. The final scores were obtained after necessary reviews and corrections by each national government. The index covers 18 aspects of EPLs grouped into three broad categories: laws that protect workers who have signed regular contracts with their employers, laws that affect workers with fixed-term and/or temporary contracts or contracts with temporary work agencies, and regulations that apply to collective dismissals.

\footnotetext{
${ }^{3}$ The Botero et al. (2004) index presents an alternative to Allard's index. Although their index is constructed for 85 countries, it is available only for 1997. Therefore, it is not suitable for investigating the causal impact of labor laws on privatization, which necessitates controlling for observable and unobservable time-varying heterogeneity. The Deakin, Lele, and Siems (2007) index presents another alternative to Allard's index. While their index provides substantial time-series variation, it is available only for the United States, the United Kingdom, France, Germany, and India. Since there were very few privatization deals in the United States before 2008 and privatization data for India are not included in the Privatization Barometer database, using the index from Deakin, Lele, and Siems (2007) would restrict our sample to three countries. Thus, we use the Allard (2005) index.
} 
The regular contracts index focuses on the procedural requirements to be followed once a decision is taken to fire an employee with a regular employment contract, the mandatory notice period, requirements for severance pay, and the prevailing standards of and penalties for unfair dismissals. Employment protection laws protect workers covered under regular contracts from dismissals resulting from economic factors such as bankruptcy, complete or partial liquidation of the enterprise, and changes in the production technology or the structure of the enterprise and to the employer's financial problems. In such cases, the redundant worker enjoys protection in the form of a notice period combined with severance pay. Other reasons for employment termination with notice include longterm absence from work for health reasons, unsatisfactory work performance due to health problems or inadequate qualifications, and refusal to relocate with the enterprise or one of its parts. In some countries, age and eligibility for old-age pension are also valid reasons for employment termination with notice, while in other countries such a termination is unlawful. The temporary-contracts index evaluates the conditions under which these types of contracts can be offered, the maximum number of successive renewals, and the maximum cumulative duration of a temporary employment contract. The collective dismissals index defines a collective dismissal and specifies the notification requirements and the associated delays and costs for employers.

\subsubsection{Within-Country Variation in the Index}

Figure 1 shows the evolution of the EPL index for the 14 OECD countries for which both the privatization data and the EPL index are available. As can be seen by examining Figure 1, there is considerable time-series variation among the countries in our sample.

The time-series variation in a country is generated by changes in laws relating to employment protection. For example, in France, laws relating to the notification of employees' dismissals were weakened in 1986. Before this change, an employer was required to provide the employee with written reasons for his or her dismissal. Furthermore, the employer had to obtain the permission of a state or local body prior to any dismissal. In 1986, this law was changed so that the employer only had to notify the state or local body prior to a dismissal. Consistent with this change in law, in Figure 1 we see the EPL index for France decreasing in 1986. The list of changes in Table 1 is derived from those described in Bertola, Boeri, and Cazes (1999) and the OECD (1999).

The summary statistics in Table 2 show that the EPL index for our sample ranges from a minimum of .8 to a maximum of 4.1 , with higher values indicating stronger employment protection. The average value of the EPL index is 2.6, and the median is very similar at 2.4. The time-series variation within countries as well as the cross-sectional variation among countries observed in Figure 1 results in a standard deviation of .8 for the EPL index. We thus conclude that the EPL index exhibits considerable variation in our sample. 


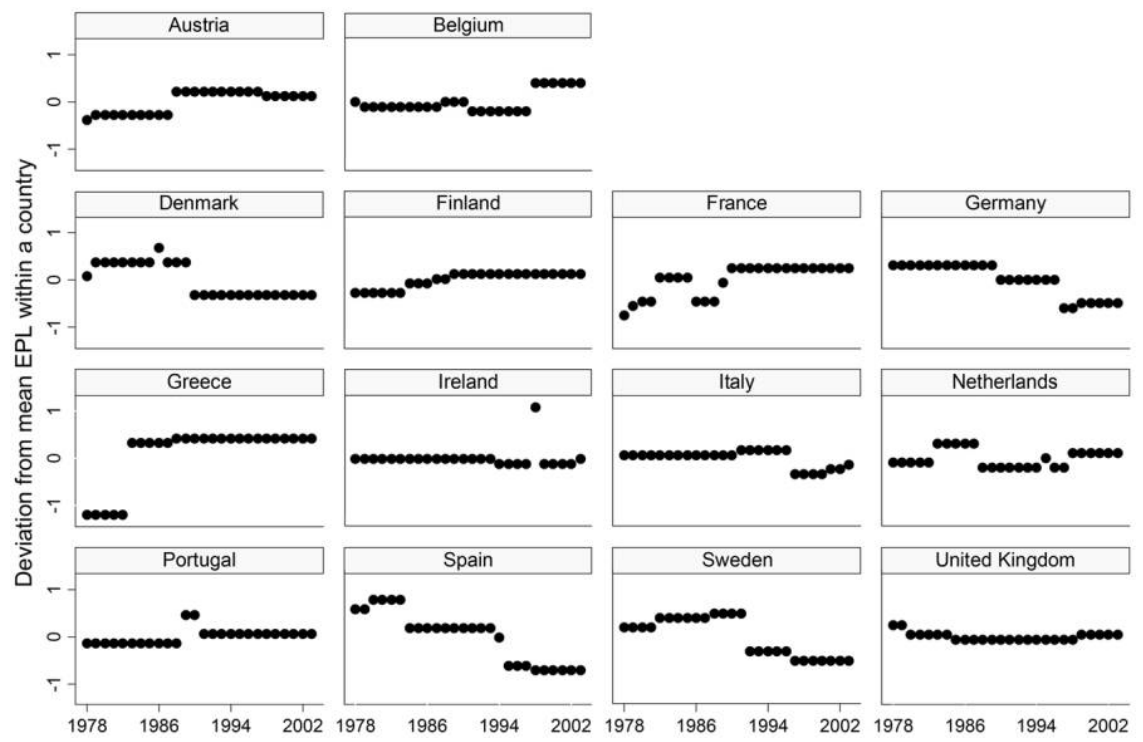

Figure 1. Variation in the employment protection legislation index

We note that there is considerable variation in the number of privatization deals and the dollar value of the privatization deals both at the country-year and the country-industry-year levels in Table 2. Table 3 decomposes the variation in EPLs and privatization into the variations between countries and within countries. By comparing the standard deviations of EPLs and privatization between countries and within countries, we note that approximately one-third of the variation in EPLs and one-third of the variation in privatization stem from within a country.

\section{Results}

We investigate whether stringent EPLs lead to less privatization. As EPLs may correlate with other country-level unobserved factors, we utilize within-country variation in EPLs to infer the causal relationship.

\subsection{Difference-in-Differences Tests Using Major Changes in Laws}

Figure 2 depicts a difference-in-differences test that examines the effect of the passage of the EPLs in Sweden in 1992: this change lowered the EPL index for Sweden by .9. The figure plots for Sweden and the United Kingdom the logarithm of total value privatized in each year divided by the total value privatized in 1992. (Values on the $y$-axis are normalized to 1991 to enable comparison.) This normalization allows us to examine the impact of the decrease in the EPL index in Sweden in 1992; there is no change in the EPL index for the United King- 


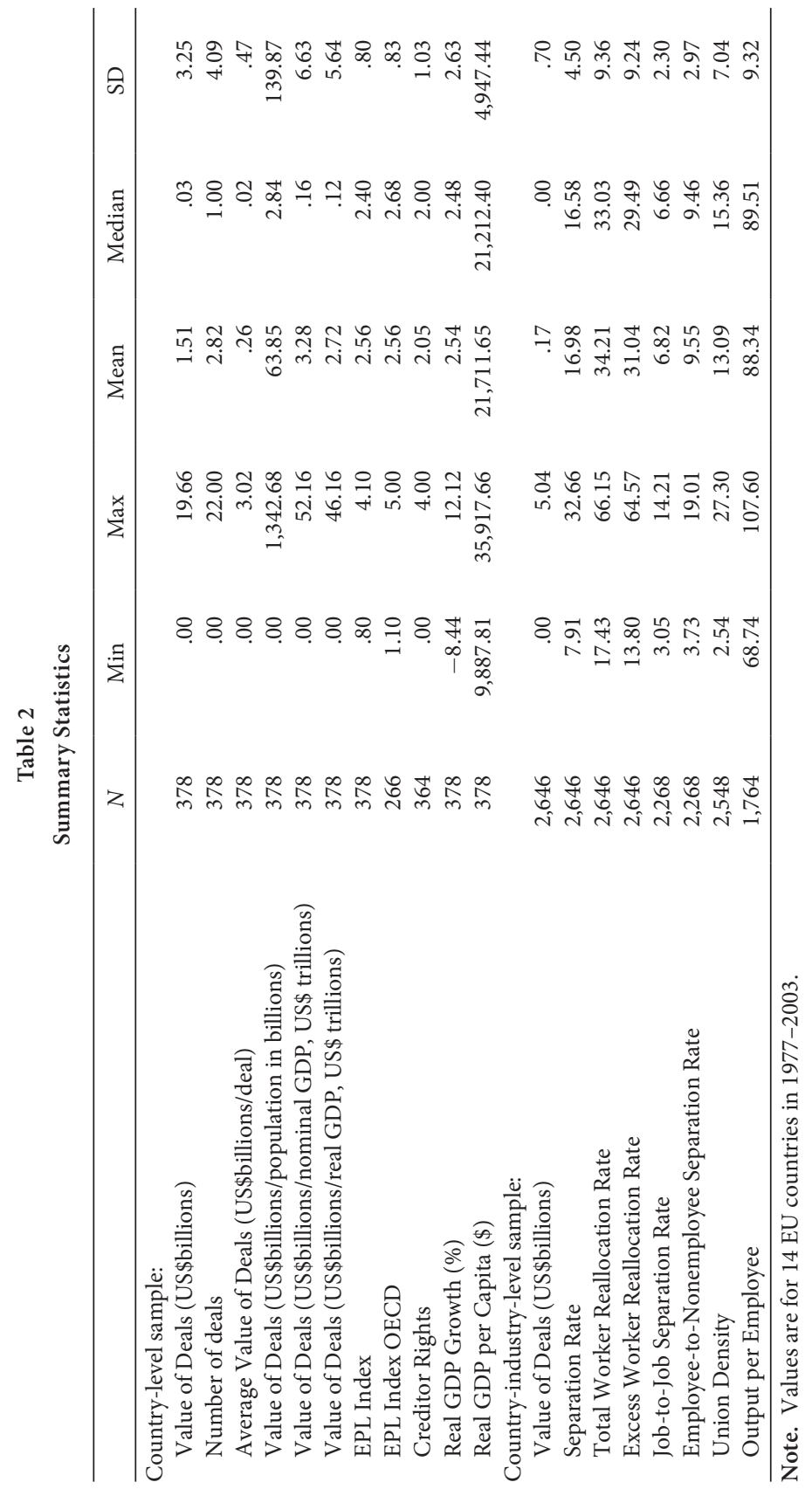

This content downloaded from 202.174.120.162 on June 08, 2019 06:35:35 AM All use subject to University of Chicago Press Terms and Conditions (http://www.journals.uchicago.edu/t-and-c). 
Table 3

Within-Country Variation in Employment Protection Laws and Privatization

\begin{tabular}{lcccc}
\hline & SD & Min & Max & Observations \\
\hline EPL Index: & & & & \\
$\quad$ Overall & .79 & 1.3 & 4.1 & 364 \\
$\quad$ Between & .73 & 1.4 & 3.65 & 14 \\
$\quad$ Within & .36 & .89 & 3.66 & 26 \\
$\quad$ Value of Deals (US\$billions): & & & & \\
$\quad$ Overall & 3.45 & 0 & 26.71 & 364 \\
$\quad$ Between & 1.59 & .22 & 4.89 & 14 \\
$\quad$ Within & 3.08 & 3.31 & 23.4 & 26 \\
\hline
\end{tabular}

dom in this period. Figure 2 clearly illustrates that after employment protection decreased in Sweden in 1992, the value of privatization deals increased substantially, while there is little change in this variable over the same period in the United Kingdom. As seen in Table OA2 in the Online Appendix, we find similar evidence using two-country difference-in-differences tests that exploit the major changes in EPLs across the countries in our sample.

\subsection{Generalized Difference-in-Differences Tests Using All Changes in Laws}

We implement a fixed-effects panel regression using the privatization proxies at the country-year level. We employ the following specification:

$$
y_{c t}=\alpha_{c}+\alpha_{t}+\beta_{1} \times \mathrm{EPL}_{c t}+\beta \boldsymbol{X}_{c t}+\varepsilon_{c t},
$$

where $y_{c t}$ is the measure of privatization for country $c$ in year $t$ and $\alpha_{c}$ and $\alpha_{t}$ denote country and year fixed effects, respectively. The term $\mathrm{EPL}_{c t}$ denotes the stringency of EPLs based on the EPL index value for country $c$ in year $t$. The country fixed effects control for time-invariant unobserved factors at the country level, and the period fixed effects control for common global trends in privatization. The set of control variables $\boldsymbol{X}_{c t}$ includes creditors' rights as they correlate with economic growth (Acharya and Subramanian 2009), gross domestic product (GDP) growth rate to control for time-varying economic conditions, and logarithm of real GDP per capita and logarithm of the population to proxy for a country's size. These panel regressions implement a generalized difference-in-differences test in multiple treatment groups and multiple time periods.

Table 4 shows the results of the test of equation (1). We find the coefficient on the EPL index to be negative and significant at the 1 percent level for the value, number, and average value of privatization deals. This result indicates that strong EPLs are negatively correlated with privatization. The decrease in the price, as captured by the average price paid, and the quantity, as captured by the number of privatization deals, is consistent with EPLs leading to a disproportionate decrease in the demand for privatization from private investors when compared with the decrease in the supply of SOEs that can be privatized. 


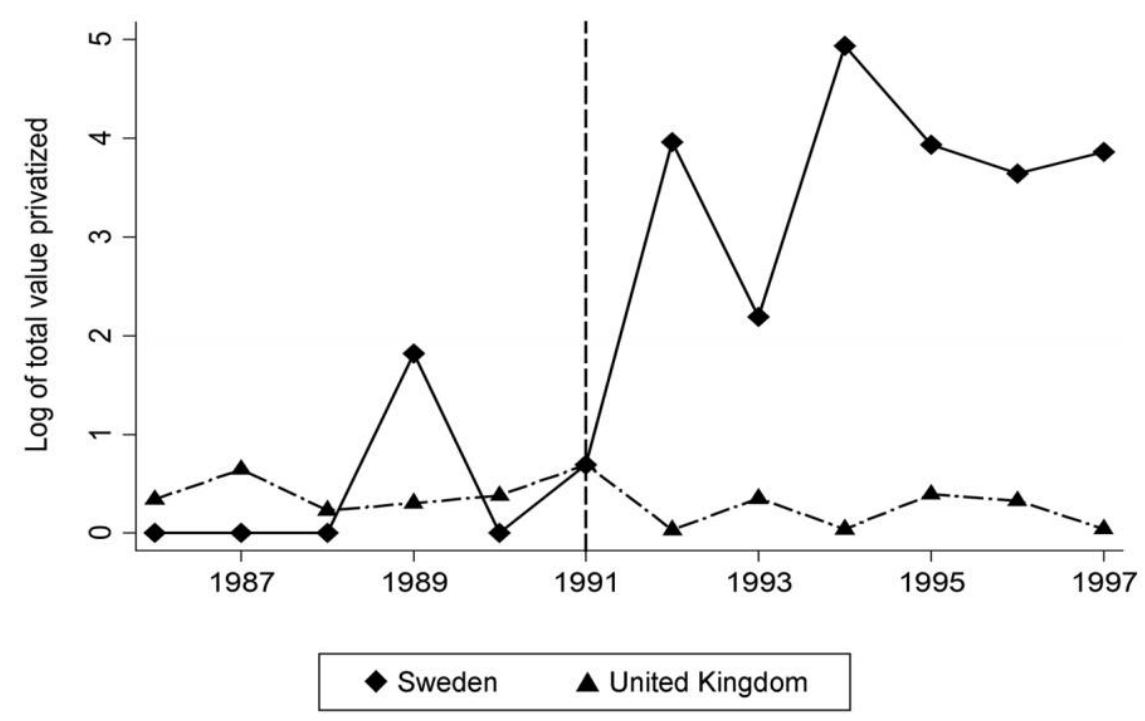

Figure 2. Difference-in-differences effect of change in employment protection legislation in Sweden in 1992.

Economically, a 1-standard-deviation decrease in EPLs (=.8 from Table 1) is associated with an increase in the value, number, and average value of privatization deals of about 29,49 , and 21 percent, respectively, when compared to the standard deviation of these variables. Thus, the magnitude of the effect of EPLs on privatization is large.

\subsection{Controlling for Endogeneity with Country-Specific Time Trends}

A key identifying assumption in a difference-in-differences estimation is that counterfactual trend behavior in the treatment and control groups is the same (Angrist and Pischke 2008). As our initial test of whether the correlation between EPLs and privatization is driven by this identifying assumption being violated, we incorporate country-specific time trends, as follows:

$$
y_{c t}=\alpha_{c}+\alpha_{t}+t \times \alpha_{c}+\beta_{1} \times \mathrm{EPL}_{c t}+\beta \boldsymbol{X}_{c t}+\varepsilon_{c t},
$$

where $t \times \alpha_{c}$ is a time trend specific to each country $c$ in our sample that accounts for country-specific time trends in privatization and EPLs and therefore controls more tightly for the effect of time-varying country-level omitted variables. Tests incorporating these time trends as controlling variables added to the specifications reported in columns 1-3 provide results that are similar to those in columns $1-3$; we omit reporting them for brevity. In column 4, we report the results of tests using equation (2) but with the value of deals per unit of nominal GDP as the dependent variable to explicitly account for the effect of a country's size on 


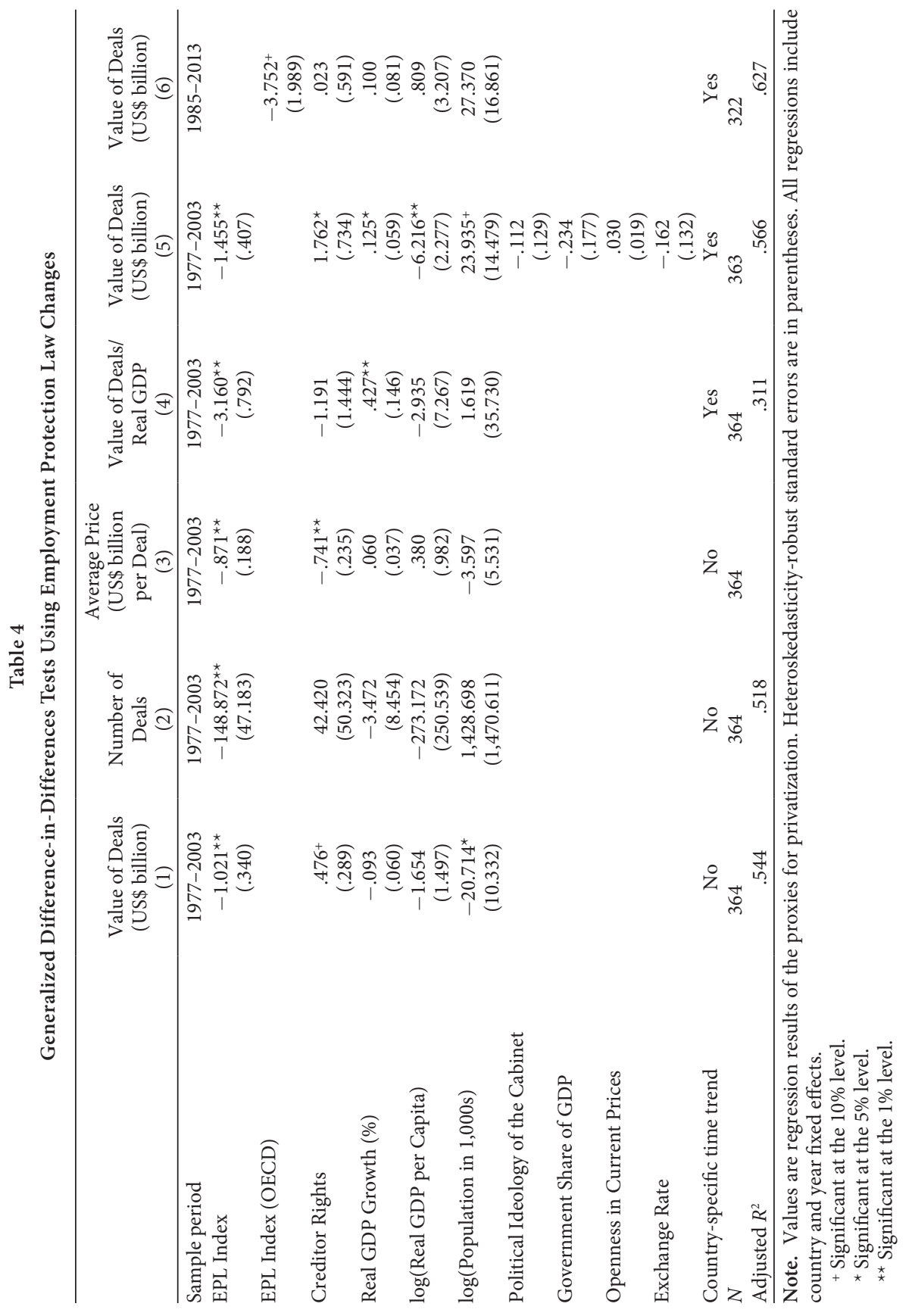

This content downloaded from 202.174.120.162 on June 08, 2019 06:35:35 AM All use subject to University of Chicago Press Terms and Conditions (http://www.journals.uchicago.edu/t-and-c). 
the size of its privatization program. We find that the statistical and economic significance of the estimates of EPL Index remain similar. As described in Section 3, EPLs and privatization may be simultaneously determined because of the effect of the political economy on both. Thus, in column 5, we report the results of tests that control for such omitted variables. The variable Political Ideology of the Cabinet, from Armingeon et al. (2008), captures the balance of power between leftand right-leaning parties in a given country's parliament. To control for other political factors that may affect the relationship between EPLs and privatization, we also include the time-varying estimate of government's share in production in the country; the aggregate level of imports into and exports from a country to proxy trade reforms, as such reforms should result in an increase in imports and exports; and the exchange rate of the country's domestic currency with respect to US dollars as a measure of trade openness. Crucially, after controlling for these political-economic factors, our results remain strong.

\subsection{Robustness to Measurement of Employment Protection Laws}

To reassure ourselves that the documented effects of EPLs are not the artifact of the way in which EPLs are measured in the Allard (2005) index, we use an alternative index of labor laws compiled by the OECD. Since the OECD index is available only from 1985 onward and several key changes in EPLs occurred in the 1970s, the index is not well suited for the main analysis that we undertake here. Using the OECD index, however, we are able to extend our sample to 2013 in specifications that do not contain control variables. In specifications containing our usual set of control variables, we extend the sample to 2008, as the data on creditors' rights are not available after 2008. We use the index of "strictness of employment protection-individual and collective dismissals (regular contracts)," denoted EPRC_v1 in the OECD index, and the specification in equation (2). Although our results remain similar to those using the three proxies for privatization, we report the results using the value of deals as the dependent variable. Column 6 of Table 4 reports the results of this test, where we find that the coefficient estimate of $\beta_{1}$ is uniformly negative, although the economic magnitude is significantly higher. This corroborates our previous findings by showing that our results are not specific to a particular EPL index. Instead, our results stem from the changes in EPLs that various indices capture.

\section{Triple-Difference Tests Controlling for Country-Level Variables}

Despite the strong results obtained with tests that include separate time trends for each country (and each industry), we are careful not to attribute a causal interpretation to our results. The concern may remain that omitted variables at the country level drive the relationship between EPLs and privatization. Since EPLs vary by country-year and any country-level omitted variable would vary by country-year as well, it is difficult to identify the hypothesized effect by aggregating privatization at the country level. We therefore exploit variation in the effect 
of EPLs on privatization in industries in a country to identify this effect. These tests rely on the idea that the effect of EPLs on privatization is likely to be larger in industries in which dismissal regulations are more binding. The intrinsic propensity of firms in an industry to adjust their workforce through layoffs depends on technological and/or market-driven factors that are idiosyncratic to the industry (Bassanini et al. 2010). In an industry with a high propensity to restructure, EPLs are more likely to distort efficient resource reallocation. Given the political considerations involved in laying off workers in SOEs, such distortions are likely to be disproportionately larger for SOEs than for privately owned firms. Therefore, changes in EPLs are likely to impact privatization disproportionately more in industries where the intrinsic propensity to restructure is high than where it is low.

\subsection{Tests Based on Hiring and Separation Rates}

For triple-difference tests using industry-level hiring and separation rates, we use a sample in which privatization varies by country-industry-year and employ panel regressions that include fixed effects for each country-year pair to control for omitted variables at the country-year level. We estimate the following specification:

$$
y_{i c t}=\alpha_{c t}+\alpha_{i}+\left(\beta_{1} \times \mathrm{EPL}_{c t}+\beta_{2}\right) \times \text { Separation }_{i c}+\beta \boldsymbol{X}_{c t}+\varepsilon_{i c t},
$$

where Separation ${ }_{i c}$ denotes the cross-sectional estimate for average separation rates in industry $i$ in country $c$ and $\alpha_{i}$ denotes the fixed effects for industry $i$. Note that the effect of EPL is subsumed by the fixed effects for each country-year pair. The term $\beta_{1}$ is the coefficient of interest, since it measures the triple-difference estimate of EPLs on privatization depending on separation rates in an industry:

$$
\begin{aligned}
\beta_{1}= & \left\{\left.\frac{\partial y_{i c t}}{\partial \operatorname{Separation}_{i c}}\right|_{\text {after }}-\left.\frac{\partial y_{i c t}}{\partial \text { Separation }_{i c}}\right|_{\text {before }}\right\}_{\text {treatment }} \\
& -\left\{\left.\frac{\partial y_{i c t}}{\partial \text { Separation }_{i c}}\right|_{\text {after }}-\left.\frac{\partial y_{i c t}}{\partial \text { Separation }_{i c}}\right|_{\text {before }}\right\}_{\text {control }} .
\end{aligned}
$$

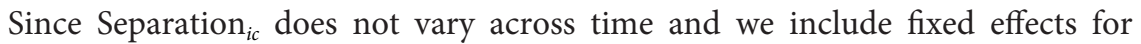
the industry and each country-year pair, this test utilizes exogenous variation through the interaction of $\mathrm{EPL}_{c t}$ and Separation ${ }_{i c}$.

Table 5 shows the results of the tests of equation (3). As described in Section 1, the effect of EPLs on privatization should be disproportionately greater in industries where separation rates are high than where they are low. The data for separation rates are from Bassanini et al. (2010), who define separation rates as the annual rate of separation of workers in an industry in a country, where separations include workers who were with the firm in year $t-1$ but not in year $t$. Bassanini et al. (2010) generate a time-invariant measure of separation rates by calculating 
Table 5

Triple-Difference Estimates Controlling for Country-Level Variables

\begin{tabular}{|c|c|c|c|c|c|}
\hline & (1) & (2) & (3) & (4) & (5) \\
\hline EPL Index $\times$ Separation Rate & $\begin{aligned}-.008^{+} \\
(.004)\end{aligned}$ & & & & \\
\hline EPL Index $\times$ Total Worker Reallocation Rate & & $\begin{array}{l}-.005^{* *} \\
(.002)\end{array}$ & & & \\
\hline EPL Index $\times$ Excess Worker Reallocation Rate & & & $\begin{array}{r}-.004^{*} \\
(.002)\end{array}$ & & \\
\hline EPL Index $\times$ Union Density & & & & $\begin{array}{l}.009^{+} \\
(.005)\end{array}$ & \\
\hline EPL Index $\times$ Output per Employee & & & & & $\begin{array}{r}-.005^{*} \\
(.003)\end{array}$ \\
\hline Separation Rate & $\begin{array}{l}.022^{+} \\
(.012)\end{array}$ & & & & \\
\hline Total Worker Reallocation Rate & & $\begin{array}{l}.011^{*} \\
(.005)\end{array}$ & & & \\
\hline Excess Worker Reallocation Rate & & & $\begin{array}{l}.009^{+} \\
(.005)\end{array}$ & & \\
\hline Union Density & & & & $\begin{array}{l}-.043^{* *} \\
(.016)\end{array}$ & \\
\hline Output per Employee & & & & & $\begin{array}{l}.014 \\
(.016)\end{array}$ \\
\hline$N$ & 2,646 & 2,646 & 2,646 & 1,764 & 2,548 \\
\hline$R^{2}$ & .333 & .333 & .333 & .369 & .337 \\
\hline
\end{tabular}

Note. Values are marginal effect of employment protection laws on privatization in industries with high hiring and separation rates and industries with high share of temporary workers using a balanced panel data set at the country-industry-year level. Hiring rates can be decomposed into job-to-job hiring rates and nonemployment-to-employment hiring rates; separation rates can be decomposed into job-to-job separation rates and employment-to-nonemployment separation rates. Industries are classified using one-digit standard industrial classification codes. All regressions include countryyear and industry fixed effects; hence, variables varying at the country-year level are absorbed. Heteroskedasticity-robust standard errors clustered by country-year are in parentheses. The sample includes privatization deals in 14 countries in seven industries, 1978-2003.

+ Significant at the $10 \%$ level.

* Significant at the $5 \%$ level.

** Significant at the $1 \%$ level.

the averages of these variables over their sample period for each industry in each country in Europe.

In column 1 in Table 5, we find that the coefficient estimate for $\beta_{1}$ is negative and statistically significant. The negative coefficient indicates that the effect of EPLs on privatization is disproportionately greater in industries where the separation rate is higher than where it is lower. As our second proxy for an industry's intrinsic propensity to restructure, we use total worker reallocation rates. In column 2, we replace separation rates with total worker reallocation rates and find that the coefficient estimate for $\beta_{1}$ is negative and statistically significant. The negative coefficient indicates that the effect of EPLs on privatization is disproportionately greater in industries where the total worker reallocation rate is higher than where it is lower. As our third proxy for propensity to restructure, we use 
excess worker reallocation rates. Bassanini et al. (2010) define excess worker reallocation as the difference between total reallocation of workers in industry $j$ at time $t$ and the industry's absolute net change in employment. According to Bassanini et al. (2010), excess reallocation of workers provides a useful measure of workforce reallocation in an industry over and above the minimum necessary to accommodate net changes in employment. In column 3, we replace separation rates with excess worker reallocation rates and find that the coefficient estimate for $\beta_{1}$ is negative and statistically significant. The negative coefficient indicates that the effect of EPLs on privatization is disproportionately greater in industries where the excess worker reallocation rate is higher than where it is lower.

To estimate the economic effect of separation rates on the effect of EPLs on privatization, we use the industry with the median separation rate as the benchmark, where the coefficient of EPL equals $-.133(=-.008 \times 16.6)$. In the benchmark industry, a 1-standard-deviation increase in EPL would reduce the amount of privatization by $\$ 106.1$ million $(=.8 \times-.133$ billion). Now consider an industry in which the separation rate is 1 standard deviation greater than that in the median industry: the coefficient of EPL would equal $-.168(=-.008 \times 21.1)$. In the benchmark industry, a 1-standard-deviation increase in EPL would reduce the amount of privatization by $\$ 134.9$ million $(=.8 \times-.168$ billion). Therefore, compared with the benchmark industry, the effect of EPLs on privatization is 27 percent greater in an industry where the separation rate is higher by 1 standard deviation. The economic magnitudes using reallocation rates are quite similar.

\subsection{Tests Using US Industry Measures}

As the second step in our identification strategy, we exploit the fact that the United States is not part of our sample to employ productivity measures for US industries as an instrument for the productivity of a given industry in a given country in our sample. The instrument satisfies the exclusion criterion for the following reasons. First, industry-level productivity measures for the United States cannot be correlated in unobserved ways with the privatization outcomes in any country in our sample. Second, such industry-level measures for the United States cannot be correlated with unobserved factors coinciding with the changes in EPLs in our sample. This instrument satisfies the relevance criteria as well for the following reasons. First, since labor market frictions at the federal level are much lower in the United States than in Europe, productivity measures for US industries approximate well the efficient level of productivity that would be obtained in an industry in the absence of stringent EPLs. Second, because the underlying technology in an industry is similar across countries, the industry-level productivity measures computed for the United States are likely to be correlated with those in an industry in a country in our sample. In fact, we find this correlation to be .62. Third, since the efficiency gains from shedding excess labor would be the greatest in less productive industries, the hurdles imposed by EPLs would be greater in less productive industries than in more productive ones. So produc- 
tivity measures for US industries serve as an exogenous proxy. We now undertake triple-difference tests in equation (5):

$$
y_{i c t}=\alpha_{i}+\alpha_{c t}+\left(\beta_{1} \times \mathrm{EPL}_{c t}+\beta_{2}\right) \times \text { LaborProductivity_US }_{i t}+\beta \boldsymbol{X}_{c t}+\varepsilon_{i c t},
$$

where $\beta_{1}$ is the variable of interest. Since the frictions arising from labor laws are absent at the US federal level, the productivity measures for the United States provide a benchmark estimate for productivity in the industry that is close to the efficient level that would prevail in the absence of labor laws. Given the inclusion of fixed effects for each country-year pair, therefore, the interaction of countrylevel EPLs with the level of productivity in the matched US industry provides us with completely exogenous variation to identify the effect of EPLs on privatization.

In column 4 of Table 5, we show the results of estimating equation (5) using output per worker as a measure of productivity. We find that the coefficient of the interaction term is consistently and significantly positive, which implies that the marginal effect of EPLs is greater in industries where employees' productivity is low than where it is high. We thus conclude that the effect of EPLs is more pronounced in less productive industries than in more productive ones.

In column 5, we show the results of triple-difference tests using the equation

$$
y_{i c t}=\alpha_{i}+\alpha_{c t}+\left(\beta_{1} \times \mathrm{EPL}_{c t}+\beta_{2}\right) \times \text { UnionDensity_US }_{i t}+\beta \boldsymbol{X}_{c t}+\varepsilon_{i c t},
$$

where UnionDensity_US ${ }_{i t}$ is the percentage of employees in industry $i$ in year $t$ represented by unions. We find that the coefficient of the interaction term is negative and statistically significant, which implies that the marginal effect of EPLs is greater in industries where employees are more unionized than in where they are less unionized.

\subsection{Discussion}

The above triple-difference tests control for various determinants of privatization at the country level and possible sources of endogeneity that could manifest in the tests we have undertaken so far. In this section, we discuss such determinants and how the triple-difference tests control for them. In general, the inclusion of fixed effects for each country-year pair enables us to control for the effect of any country-level determinant. Furthermore, the interaction with timeinvarying measures for separation and reallocation rates at the industry level and the interaction with exogenous measures for industry-level productivity for the United States ensure that our results cannot be driven by omitted variables at the industry level either.

Privatizable State-Owned Enterprises and Privatization Waves. First, governments undertaking privatization transactions may be fearful of the political fallout of selling the family silver cheap. Therefore, having obtained higher prices for privatized companies in the past may increase a government's willingness to privatize now. Second, the fear of such political fallout may also lead to privatization 
being impacted by inventory depletion effects, the likelihood that greater privatization in a country through time $t-1$ will reduce the inventory of privatizable firms in that country and thereby reduce the likelihood of privatization in time $t$. Third, privatization deals tend to occur in waves. Finally, the government's reservation price and the private sector's willingness to pay for SOEs may account for privatization.

Changes in Enforceability of Laws. While the term EPL captures the strength of EPLs as enacted, time-varying differences in enforcement of these laws could spoil identification in country-level tests. Such time-varying differences may influence privatization as well.

Correlation of Changes in Law with Changes in Government. Changes in a country's EPLs are likely to be correlated with changes in elected governments. In particular, to cater to their political constituencies, more left-leaning governments may be inclined to strengthen labor laws. Botero et al. (2004) find that countries with a longer history of leftist governments have more stringent labor regulation. Leftist governments are also less likely to privatize SOEs.

Correlation of Changes in Law with Trade Reforms. Since trade liberalization in a country may result in job losses, governments may enact stringent EPLs following trade liberalization. The OECD (2005) estimates that international trade accounted for up to 4 percent of all permanent layoffs in Canada, the United States, and the European Union in 2000. Furthermore, trade liberalizations may coincide with other structural reforms such as privatization.

Correlation of Changes in Law with Government Share in Production. The literature on economic growth suggests that government involvement in economic production serves as a proxy for the level of political corruption in a country (Cook and Uchida 2003). Greater political corruption may lead governments to enact stringent EPLs in order to cater to their political constituencies. Similarly, political pressure exerted by influential groups may force the government to avoid privatization.

The inclusion of fixed effects for each country-year pair enables us to control for the effect of all these country-level determinants. Therefore, we conclude that the negative effect of EPLs on privatization estimated in the tables is unlikely to be driven either by other determinants of privatization or by omitted variables that may have caused EPLs and privatization to be simultaneously determined.

\subsection{Analyses of Codetermination of Changes in Law and Privatization}

The correlation of the EPL index with the ideological leanings of a country's government is .18, which is quite low. Furthermore, the correlation of changes in the EPL index with the variable Ideological Gap between New and Old Cabinets is .07 , which is insignificant. Thus, the overall correlation between the ideological leanings of a government and EPLs is negligible in our sample. Nevertheless, here we examine the intertemporal linkages between the timing of privatization programs and changes in EPLs for each country to further investigate the possibility 
that EPLs and privatization are simultaneously determined. Such simultaneous determination could result from a change in national government that brings an ideologically charged party to power. As described in Section 3, this arguably is the case for the Thatcher government in the United Kingdom.

To examine whether the Thatcher phenomenon was an exception or the norm, we compare the timing of changes in EPLs shown in Figure 1 with the timing of national privatization program waves described by Megginson (2005) and in the PB database. Such a comparison reveals no other example in which the beginning or ending of a national privatization wave coincided sharply with major changes in a nation's EPLs. In Germany and Italy, the largest reductions in EPLs followed the initiation of significant privatization programs, while in Austria, Belgium, Greece, and Sweden more stringent EPLs were enacted years before the largest privatization programs began. While Sweden subsequently reduced the stringency of EPLs before a second privatization wave began in the early 1990s, both changes in policy may have been prompted more by the financial crisis that led Sweden to nationalize its banks in 1992 and then reprivatize them years later. The stringency of EPLs declined more or less continuously (with brief upward jumps) for Spain and Denmark over the 1978-2003 period, but both countries' major privatization waves began several years after these changes in EPLs were begun. Employment protection laws were very stable throughout most of the period of our study (again with brief upticks) for Ireland and Portugal, even though Ireland implemented a few privatizations during the 1990s and Portugal launched a massive program in 1989 that cut state ownership in Portuguese SOEs by more than half over the next decade. Only for France and the Netherlands does there appear to be any real temporal linkage between frequent changes in the stringency of EPLs-both up and down-and privatization waves. Reductions in the stringency of French EPLs in 1986-88 coincided with the very large privatizations of the first Chirac government, and reductions in the stringency of Dutch EPLs during 1988-93 also coincided with a significant wave of privatizations by center-right governments. However, after 1988 in France and after 1993 in the Netherlands, both countries strengthened their EPLs yet also witnessed their largest ever privatization waves. In tests that we omit for brevity, we investigated whether the results change when we exclude Britain, France, and the Netherlands from the sample; we found that our results are very similar with or without these three countries. In sum, the tests directly accounting for endogeneity in the fixed-effects panel regressions and the case-by-case examination of the simultaneity of changes in EPLs and privatization complement the compelling evidence of the negative effect of EPLs on privatization. Taking these facts together, we can conclude that even in our country-level tests, EPLs dampen privatization.

\section{Conclusion}

Do employment protection laws hinder privatization? Using privatization deals in 14 EU countries from 1978 to 2003 and within-country variation in EPLs, we 
find a robust negative correlation between EPLs and privatization. The fear of job losses following government divestment leads organized labor in SOEs to vehemently oppose privatization. Consistent with the fear of retrenchment being greater in less productive and low-skilled sectors and the fact that such groups of workers exert considerable political pressure, we find that stringent EPLs inhibit privatization disproportionately more in industries that are less productive and have lower hiring rates and higher separation rates. After accounting for the potential endogeneity of EPLs, we conclude that, quite plausibly, stringent EPLs deter privatization. In particular, EPLs significantly reduce the value of privatization in a country. The effect of EPLs on the number of deals and the average value per deal remain similar although statistically insignificant at times, which points to the difficulty in disentangling the aggregate effect on the value of deals into these two variables.

We contribute to the law and finance and privatization literatures by being the first to examine the effect of country-level labor laws on privatization. We investigate how laws that affect a key relationship in corporations-that between employers and employees-impact the transition of corporate ownership from the state to private entities. Since we utilize the universe of all privatization transactions and EPL changes in the 14 European countries for which we obtain data, we are able to document a robust correlation between these two key country-level variables. Using the universe of employment protection changes does not come without a cost, however: the changes in law in our study do not provide strictly exogenous variation in EPLs. While we attempt and make substantial progress in identifying the causal relationship between EPLs and privatization by accounting for such endogeneity in several ways, studies using natural experiments that provide exogenous variation in EPLs would be able to determine the causal connection, albeit in a specialized setting. Thus, such analyses would serve as effective complements to our study. Furthermore, studies examining the effect on privatization of other laws, such as those that affect the protection offered to minority shareholders and those relating to the takeover of firms, would enhance our understanding of the effects of the legal environment in a country on such an important country-level policy variable as privatization. Since our analysis includes 14 countries in the European Union, our results may not necessarily be generalizable to other countries. Given governments' dominance in economic activity in Asian economies, on the one hand, and the general stringency of labor regulation in these economies, on the other hand, examining the effect of labor regulation on privatization in Asian countries would enhance our understanding of this relationship across the world. Finally, our results, when taken together with those of Simintzi, Vig, and Volpin (2015), suggest that employment protection has the greatest impact on industries in which workers possess low levels of skills. Therefore, SOEs may distort the optimal allocation of resources in an economy when they are active in industries with low-skilled workers. Estimating the loss of economic surplus from government presence in commercial activity remains crucial 
to guiding governmental policies in this sphere. We suggest these as areas for future research.

\section{References}

Acharya, Viral V., Ramin P. Baghai, and Krishnamurthy V. Subramanian. 2013. Labor Laws and Innovation. Lournal of Law and Economics 56:997-1037.

. 2014. Wrongful Discharge Laws and Innovation. Review of Financial Studies 27:301-46.

Acharya, Viral V., and Krishnamurthy V. Subramanian. 2009. Bankruptcy Codes and Innovation. Review of Financial Studies 22:4949-88.

Agrawal, Ashwini K. 2011. Corporate Governance Objectives of Labor Union Shareholders: Evidence from Proxy Voting. Review of Financial Studies 25:187-226.

Agrawal, Ashwini K., and David A. Matsa. 2013. Labor Unemployment Risk and Corporate Financial Decisions. Journal of Financial Economics 108:449-70.

Alimov, Azizjon. 2015. Labor Protection Laws and Bank Loan Contracting. Lournal of Law and Economics 58:37-74.

Allard, G. 2005. Measuring Job Security over Time: In Search of a Historical Indicator for EPL (Employment Protection Legislation). Working Paper No. WP05-17. Instituto de Empresa, Madrid.

Angrist, Joshua D., and Jörn-Steffen Pischke. 2008. Mostly Harmless Econometrics: An Empiricist's Companion. Princeton, NJ: Princeton University Press.

Armingeon, Klaus, Marlène Gerber, Philipp Leimgruber, and Michelle Beyeler. 2008. Comparative Political Data Set 1960-2006. University of Berne, Institute of Political Science, Berne.

Atanassov, Julian, and E. Han Kim. 2009. Labor Laws and Corporate Governance: International Evidence from Restructuring Decisions. Lournal of Finance 64:341-74.

Bae, Kee-Hong, Jun-Koo Kang, and Jin Wang. 2011. Employee Treatment and Firm Leverage: A Test of the Stakeholder Theory of Capital Structure. Lournal of Financial Economics 100:130-53.

Banerji, Arup, and Richard H. Sabot. 1994. Wage Distortions, Over-manning, and Reform in Developing Country Public Enterprises. World Bank, Washington, D.C.

Bassanini, Andrea, Andrea Garnero, Pascal Marianna, and Sébastien Martin. 2010. Institutional Determinants of Worker Flows: A Cross-Country/Cross-Industry Approach. Social, Employment and Migration Working Paper No. 107. Organisation for Economic Co-operation and Development, Paris.

Bertola, Giuseppe, Tito Boeri, and Sandrine Cazes. 1999. Employment Protection and Labour Market Adjustment in OECD Countries: Evolving Institutions and Variable Enforcement. Employment and Training Paper No. 48. International Labour Office, Geneva.

Besley, Timothy, and Robin Burgess. 2004. Can Labor Regulation Hinder Economic Performance? Evidence from India. Quarterly Journal of Economics 119:91-134.

Blanchard, Olivier, and Pedro Portugal. 2001. What Hides Behind an Unemployment Rate: Comparing Portuguese and U.S. Labor Markets. American Economic Review 91: 187-207.

Bortolotti, Bernardo, and Mara Faccio. 2009. Government Control of Privatized Firms. Review of Financial Studies 22:2907-39.

Botero, Juan, Djankov, Simeon, La Porta, Rafael, and Florencio Lopez-De-Silanes, and An- 
drei Shleifer. 2004. The Regulation of Labor. Quarterly Journal of Economics 119:133982.

Boutchkova, Maria K. and William L. Megginson. 2000. Privatization and the Rise of Global Capital Markets. Financial Management 29:31-76.

Boycko, Maxim, Andrei Shleifer, and Robert W. Vishny. 1996. A Theory of Privatization. Economic Journal 106:309-19.

Chen, Donghua, Dequan Jiang, Alexander Ljungqvist, Haitian Lu, and Mingming Zhou, 2015. State Capitalism vs. Private Enterprise. Working paper. Nanjing University, Department of Accounting, Nanjing.

Chen, Huafeng Jason, Marcin Kacperczyk, and Hernán Ortiz-Molina. 2011. Labor Unions, Operating Flexibility, and the Cost of Equity. Lournal of Financial and Quantitative Analysis 46:25-58.

Chong, Alberto, Jorge Guillen, and Florencio López-de-Silanes. 2011. Privatization and Labor Policies. Iournal of Public Economics 95:1119-30.

Cook, Paul, and Yuichiro Uchida. 2003. Privatization and Economic Growth in Developing Countries. Lournal of Development Studies 39:121-54.

Deakin, Simon, Priya Lele, and Mathias Siems. 2007. The Evolution of Labor Law: Calibrating and Comparing Regulatory Regimes. International Labour Review 146:133-62.

DeAngelo, Harry, and Linda DeAngelo. 1991. Union Negotiations and Corporate Policy. Lournal of Financial Economics 30:3-43.

Dessaint, Olivier, Andrey Golubov, and Paolo Volpin. 2017. Employment Protection and Takeovers. Journal of Financial Economics 125:41-57.

Dewenter, Kathryn L., and Paul H. Malatesta. 2001. State-Owned and Privately-Owned Firms: An Empirical Analysis of Profitability, Leverage, and Labor Intensity. American Economic Review 91:320-34.

Dinç, I. Serdar, and Nandini Gupta. 2011. The Decision to Privatize: Finance and Politics. Lournal of Finance 66:241-69.

D'Souza, Juliet, and William L. Megginson. 1999. The Financial and Operating Performance of Privatized Firms during the 1990s. Lournal of Finance 54:1397-1438.

Du, Jun, and Xiaoxuan Liu. 2015. Selection, Staging, and Sequencing in the Recent Chinese Privatization. Iournal of Law and Economics 58:657-82.

Economist. 2014. The \$9 Trillion Sale. January 11.

Faleye, Olubunmi, Vikas Mehrotra, and Randall Morck. 2006. When Labor Has a Voice in Corporate Governance. Iournal of Financial and Ouantitative Analvsis 41:489-510.

Fauver, Larry, and Michael E. Fuerst. 2006. Does Good Governance Include Employee Representation? Evidence from German Corporate Boards. Lournal of Financial Economics 82:673-710.

Klasa, Sandy, William F. Maxwell, and Hernán Ortiz-Molina. 2009. The Strategic Use of Corporate Cash Holdings in Collective Bargaining with Labor Unions. Lournal of Financial Economics 92:421-442.

La Porta, Rafael, and Florencio López-de-Silanes. 1999. Benefits of Privatization: Evidence from Mexico. Quarterly Journal of Economics 114:1193-1242.

La Porta, Rafael, Florencio Lopez-de-Silanes, and Andrei Shleifer. 1999. Corporate Ownership around the World. Lournal of Finance 54:471-517.

La Porta, Rafael, Florencio Lopez-de-Silanes, Andrei Shleifer, and Robert W. Vishny. 1997. Legal Determinants of External Finance. Journal of Finance 52:1131-50. . 1998. Law and Finance. Lournal of Political Economy 106:1113-50.

Lazear, Edward P. 1990. Job Security Provisions and Employment. Quarterly Journal of 
Economics 105:699-726.

Ljungqvist, Lars, and Thomas J. Sargent. 1998. The European Unemployment Dilemma. Lournal of Political Economv 106:514-50.

López-de-Silanes, Florencio. 1997. Determinants of Privatization Prices. Ouarterlv Journal of Economics 112:965-1025.

Matsa, David A. 2010. Capital Structure as a Strategic Variable: Evidence from Collective Bargaining. Lournal of Finance 65:1197-1232.

Megginson, William L. 2005. The Financial Economics of Privatization. New York: Oxford University Press.

_. 2017. Privatization Major Deals and Trends in 2015 and 2016. Privatization Barometer Report. Fondazione Eni Enrico Mattei, Milan.

Megginson, William L., Robert C. Nash, Jeffry M. Netter, and Annette B. Poulsen. 2004. The Choice of Public versus Private Markets: Evidence from Privatizations. Lournal of Finance 59:2835-70.

OECD (Organisation for Economic Co-operation and Development). 1999. OECD Employment Outlook: June 1999. Paris: OECD.

- 2005. OECD Employment Outlook: 2005. Paris: OECD.

- 2014. The Size and Sectoral Distribution of SOEs in OECD and Partner Countries. Paris: Organisation for Economic Co-operation and Development.

Pagano, M., and P. F. Volpin. 2005. Managers, Workers, and Corporate Control. Lournal of Finance 60:841-68.

Saint-Paul, Gilles. 2002. The Political Economy of Employment Protection. Iournal of Political Economv 110:672-704.

Shleifer, Andrei, and Robert W. Vishny. 1994. Politicians and Firms. Quarterlv Journal of Economics 109:995-1025.

Simintzi, Elena, Vikrant Vig, and Paolo Volpin. 2015. Labor Protection and Leverage. $\underline{R e-}$ view of Financial Studies 28:561-91. 